\title{
Effect of Brand Awareness, Perceptions of Quality, Uniqueness and Social Image to Price Premium in J.CO Banda Aceh
}

\author{
Sorayanti Utami \\ Lecturer of Business Economics Faculty of Syiah Kuala University, Aceh, Indonesia \\ Raudatun Jannah \\ Alumni of Business Economics Faculty of Syiah Kuala University, Aceh, Indonesia
}

\begin{abstract}
This study aims to Determine the Effect of Brand Awareness, Perception Quality, Uniqueness and Social Image to Price Premium. The sample used in this study is the people of Banda Aceh who once consumed J.CO. This research method using Questionnaire as research instrument. Non-Probability Sampling is used as a sampling technique. Methods of testing analysis and the data analysis were done using SPSS (Statistics Package for Social Science) version 20 with the formulation of multiple regression. The results of this study indicate that Affects Price Premium Brand Awareness, Perception Affects Price Premium Quality, Uniqueness Price Premium influences, and Social Imprets Price Premium.
\end{abstract}

Keywords: Brand Awareness, Perception Quality, Uniqueness, Social Image, Price Premium

DOI: $10.7176 / \mathrm{EJBM} / 11-26-06$

Publication date:September $30^{\text {th }} 2019$

\section{Introduction}

The development of the food industry from ancient times until now has been growing rapidly. Of food only with rice, or with yeast, it has been combined with a variety of other foods as a supplement. These developments are increasingly growing up till now do not require supplementary food rice again. Therefore it is a lot of popping the unique foods that were previously rare. The development of the food is also supported by the development of the beverage which is increasingly emerging. Food and beverage industry that exists around the world competing for customers. So that now we can find a wide range of food and beverage products that have many variants in order to attract customers.

Brand is a name, term, sign, symbol or design or a combination thereof, which is expected to identify goods or services from a group of sellers and are expected to distinguish the goods or services of other competitor products (Buchory, 2010). Brands can also be used as a confidence for consumers and guarantee the quality of a product. With the brand makes consumers more interested and willing to pay more even though the product is marketed at a high price. Premium price is one aspect that causes the food and beverage industry has increased or decreased. The premium price into consideration factors customers look at the feasibility of product prices with the ability to buy such products (Shu-pei Tsai 2005). The premium price will not be separated from brand awareness, perceived quality, uniqueness and social image. Customers will still make purchases, although they know that the product is classified in the high category. In consideration that customers searching as social image of every customer.

Consciousness itself is seen as one of the most important pillars to build a brand (Johan Anselmson 2014). Brand awareness is reflected on the customer's ability to identify the brand under different circumstances (Johan Anselmson et al, 2007). Awareness of the brand to consumers, namely the satisfaction or identify consumer products purchased with the quality, uniqueness, and social image contained in the product so that consumers can remember or recognize those products. Mccording Johan Anselmsson et al, (2007) The perception of quality is customer perception of all or a superiority quality products or services related to what is expected by the customer. Johan Anselmsson et al, (2007) confirms one thing you should always keep in mind, that the perception of quality is the perception of the customer, and therefore the perception of quality can not be determined objectively. Perceptions of quality can be called as a result continuously through the process of product attributes in which it directs consumers judge the quality of a product.

Uniqueness is "the extent to which the customer feels that a different brand to brand competitors" (Netemeyer et al., 2004). Psychological reasons why uniqueness is so important that states that when consumers face a choice (between one or more brands), they tend to ignore the same attributes as an alternative, because it does not offer preferential guide, and vice versa unique attributes to be important (Matthew Jacques 2013). and it can be concluded that the uniqueness is the distinguishing characteristic of a product of the same. In consumer behavior, Consumers of a product are not only to fulfill functional and psychological needs, but also to obtain a Social Image and reward themselves, improve their status and social identity (Elliot \& Wattansawan, 1998). Social interaction may result in a change in social habits that affect patterns of social behavior, including in view of the social status result on their purchase behavior (He et al., 2012). 
One company that has a premium price, along with brand awareness, perceived quality, uniqueness and social image that is J.CO, where J.CO also sells drinks such as coffee of various types of coffee and they also make a cake like a donut and burger for sale to community. The idea of the idea to open a Donut \& Coffee J.Co because in Indonesia at the moment there is no one who has a donut outlets open kitchen concept. This makes Johnny Andrean, who had the idea and the founder J.Co Donut \& Coffee wants to promote the concept of open kitchen, so that customers can see firsthand how the process of making a hygienic donuts, which uses quality ingredients and amazing. ended on June 26, 2005 outlets J.Co first Donut \& Coffee officially opened in the Supermall Karawaci, Tangerang. Apparently with the modern concept donut business is able to attract the attention and interest of the community. So that the outlet J.Co Donut \& Coffee is always packed with visitors who are curious or addicted to sample the delights of the premium class donuts.

J.Co success Donut \& Coffee then accompany the opening of outlets J.Co Donut \& Coffee in other regions. Within 1 year, J.CO Donut \& Coffee had managed to open 16 outlets by the number of stores reached 450 employees. In 2007, J.CO Donut \& Coffee even been seeking to go international with some destination countries such as Singapore, Australia and Hong Kong. (Https://www.maxmanroe.com/melihat- sejarah-bisnis-j-co-donutcoffee.html). J.CO Donut \& Coffee also uses a peacock-shaped logo in brown and orange are dominant as a symbol of beauty, gentleness, immortality and all the good intentions for the achievement of business goals that could develop in the future.

And on 21 November 2015 J.CO Donuts and Coffee officially arrived in Aceh Suzuya Mall precisely in Banda Aceh. J.CO a first outlet in Aceh and branches to 178 in Indonesia. J.CO present in Banda Aceh due to see the development of more advanced regions and to answer customer demand for open stores J.CO in Banda Aceh. During this time the average Acehnese while traveling to Medan and other cities in Indonesia, one of the souvenirs brought home is Donut J.CO. J.CO Donuts \& Coffee Restaurant is a restaurant that serves and offer products donut with a variety of flavors that are so diverse, and the share of other product forms are provided such as coffee drinks and yogurt.

In the era of globalization with the development of a lifestyle that more and more modern, J.CO Donuts \& Coffee have to do a range of innovative variants of existing products in J.CO that has been offered to the existing donut variants in accordance with the wishes of consumers and according to consumer tastes. From the table J.CO price and KING'O that there are various kinds of products with different price categories. However, the price of the product J.CO more premium compared to poduk KING'O. Consumers prefer products J.CO compared with KING'O products, when they realize that more J.CO price premium. Of course this makes the competition very tight and becomes hotter because each company will compete for customers and scramble to get the market with their product innovations as well as in the high and low prices. This is because increasing its competitors in the food industry, which makes the consumer has many options and variations of the assortment in order to be considered from a wide range of products on offer.

J.CO company said premium because the company is using a tool that is imported from abroad food and beverage manufacturing process aided by a relatively expensive means of which the basic material used as chocolate imported from Belgium and milk from New Zealand as well as the coffee is imported from Italy and Costa Rica because it J.CO company positioned as a premium-quality product on the market donut in Indonesia (http://agung- ananda.blogspot.co.id/2011/10/jco- donuts-coffee.html). In Banda Aceh alone J.CO company has a unique product that attracted the attention of customers so that customers stick around to visit J.CO. Where now also widely present other companies that produce donut offered at a low price, while J.CO Banda Aceh to produce food and beverages by offering a premium price. With the launch of their brand awareness makes it easier for customers to remember and take pride in using it, because most customers have high social image. Customers who J.CO company target is the customer for all the groups, however, most customers who visit customers J.CO Banda Aceh is the middle class category.

In addition to product innovation in order to compete in the market and stay afloat, companies J.CO Banda Aceh should be able to have a brand or a brand in order to enable consumers to identify a product and to make the characteristic or the uniqueness of the company so that the product is different from the other products from which consumers will continue to choose the product. Based on this phenomenon of brand awareness, perceived quality, uniqueness and social image becomes an important part in the company's premium price J.CO Banda Aceh where the results of the customer interviews Banda Aceh J.CO they will still buy products J.CO in the premium price category because they found in banda Aceh have J.CO Quality, uniqueness of the products so that they are aware of the brand and to improve their social image.

\section{Literatur Review \\ Brand Awareness}

According to Johan Anselmson et al (2007), brand awareness is reflected in the ability for consumers to identify the brand under different circumstances, including the brand recognition of the brand opinion by Johan Anselmson 2014, awareness is seen as one of the most important pillars to build brand equity. 


\section{Perceived Quality}

Perceived quality by Anselmsson et al (2007) is to function and perform as expected, attractive and functional packaging, the color of the product, durability compared to other products, and the texture of the product. Perceived quality by Johan Anselmsson et al, 2007 can be defined as the overall customer perception of quality or excellence of a product or service related to what is expected by the customer.

\section{Uniqueness}

According to Matthew Jacques 2013 Uniqueness psychological reason why uniqueness is so important that states that when consumers face a choice (between two or more brands), they tend to ignore the same attributes as an alternative, because it does not offer preferential guide, and vice versa unique attributes becomes important.

\section{Social Image}

Social Image, Possess and use a product brand is a prominent factor that will be perceived by the consumer (Atwal \& Williams, 2009). According to Keller (2009), Social image is how a brand meets the needs of psychological and / or social needs.

\section{Influence Between Variables}

Effect of Brand Awareness Against Price Premium

Brand awareness is reflected on the customer's ability to identify the brand under different circumstances (Keller, 1993). In some studies, brand awareness has been shown to affect the response of customers towards the brand positively (Anselmsson et al., 2007). Anselmsson (2014) suggested that the awareness of the brand effect on the willingness of consumers to pay premium prices. Therefore, we assume that brand awareness is very important for the customer willingness to pay a premium price.

H1: Brand awareness affects the Price Premium

\section{Effect of Quality Perception Against Price Premium}

According to (Anselmsson et al., 2014) the brand may be having a good name in the eyes of consumers if the company is also concerned with the quality is good too, so that when the company installed a high price or premium price consumers will not switch to another brand and will continue to use Meret the

H2: Perceived quality affects the Price Premium

\section{Effect of Uniqueness Against Price Premium}

Uniqueness, which means "to the extent Where the customer feels that a different brand of a competitor's brand" (Netemeyer et al., 2004). According to Ali (2010) suggested that the researchers found evidence bikultural society requires their uniqueness. In the previous empirical studies, the relationship between uniqueness and premium pricing has been approved statistically (Anselmsson et al., 2014).

H3: The uniqueness of the effect on the price Premium

\section{Influence of Social Imagery Against Price Premium}

According to Harrison (2001) social image is the opinion or views of others against other individuals. So that right is very good if the company is also maintaining its brand image in the eyes of the consumer social. According Anselmsson et al., (2014) has become a social image controllers in premium prices.

H4: Social Imagery effect on Price

Premium

\section{Framework}

The framework is a framework of relationships between concepts that you want to observe and to be measured by research to be conducted. Frameworkan overview of the research conducted and provide a strong foundation terhaddap studies conducted as well as provide a strong foundationto the topics selected and adapted to the problems that occur. In order for these concepts able to be observed and measured, then translated into multiple variables in a model study. 


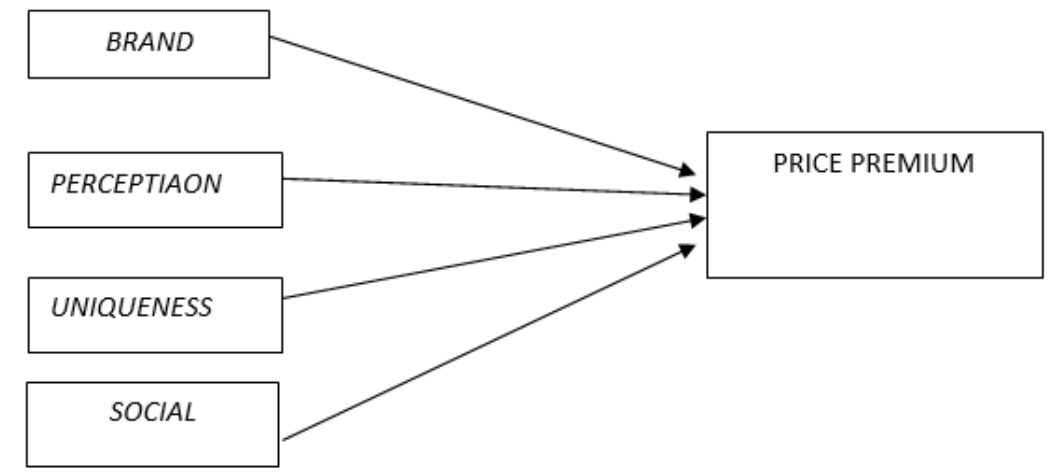

Figure 1. Framework

\section{Research Methodology \\ Location and Object Research}

This research was conducted in Banda Aceh on consumers J.CO. The object of this study are: Brand Awareness, Perceived Quality, Uniqueness and Social image as an independent variable, and Price Premium as the Dependent variable.

\section{Population and Sampling}

This study, the target population is the general public who consume foods and drinks in J.CO. Elections were conducted with non-probability sampling method and using purposive sampling technique. According to Malhotra (2009), purposive sampling is a sampling technique based on certain considerations, which are considered suitable to the characteristics of the sample were determined to be sampled. In this study, researchers took a sample of 152. The multiple linear regression model can be formulated as follows:

$\mathrm{Y}=\mathrm{b} 1 \mathrm{x} 1+\mathrm{b} 2 \mathrm{x} 2+\mathrm{b} 3 \mathrm{x} 3+\mathrm{b} 4 \mathrm{x} 4$

Information:

$\mathrm{Y}=$ Price Premium (Price Premium) X1 = Brand Awareness

$\mathrm{X} 2=$ Perceived Quality

$\mathrm{X} 3=$ Uniqueness

$\mathrm{X} 4=$ Social Imagery $\mathrm{b}=$ coefficient

\section{Data Collection Technique}

The technique of collecting data and information used in this study using a questionnaire (questionnaire). The questionnaire used is the type of choice to make it easier for respondents to give an answer, because the alternative answers are provided and only takes a shorter time to answer it. The questionnaire will be given to the respondent a questionnaire given through a google form.

\section{Operational Variables}

Operational variables in this study is a premium price as the dependent variable (Y) and the independent variable $(\mathrm{X})$ in this study is the Brand Awareness, Perceptions of quality, uniqueness, and Social Imagery.

\section{Data Analysis Equipment}

Testing and analysis of primary data done using the SPSS (Statistics Package for Social Science) version 20 with the formulation of multiple linear regression. In accordance with the objectives of this study to determine the effect of Brand Awareness, Perceived Quality, Uniqueness and Social Imagery against Price Premium (Price Premium) on J.CO Banda Aceh, it can be understood that Brand Awareness (X1), Perceived Quality (X2), uniqueness (X3), Social Imagery (X4) and Price Premium (Y).

\section{Results And Discussion \\ Characteristics of Respondents}

This research was conducted on the Community that Never consume food and beverages inJ.CO DONUTS \& COFFEE with the appropriate criteria set by the researchers. The author took a sample of 152 respondents. This study was done on people who consume J.CO in Banda Aceh characteristics of respondents about the level of the respondent age, gender, education level of the respondent, the respondent job and income / monthly allowance of respondents. The authors then identify the characteristics of the respondents as shown in the table below: 
Table 1. Descriptive Statistics Characteristics of Respondents

\begin{tabular}{|c|c|c|c|}
\hline No & Information & Frequency & Prestase \\
\hline \multirow[t]{6}{*}{1.} & Age & & \\
\hline & 18-25 Years & 139 & $91.4 \%$ \\
\hline & 26-30 Years & 10 & $6.6 \%$ \\
\hline & $31-35$ Years & 2 & $1.3 \%$ \\
\hline & $>35$ Years & 1 & $0.7 \%$ \\
\hline & Total & 152 & $100 \%$ \\
\hline \multirow[t]{4}{*}{2.} & Gender & & \\
\hline & Man & 55 & $36.2 \%$ \\
\hline & woman & 97 & $63.8 \%$ \\
\hline & Total & 152 & $100 \%$ \\
\hline \multirow[t]{6}{*}{3.} & Education & & \\
\hline & High School & 39 & $25.7 \%$ \\
\hline & Diploma 111 & 24 & $15.8 \%$ \\
\hline & $\mathrm{S} 1$ & 81 & $53.3 \%$ \\
\hline & S2 & 8 & $5.3 \%$ \\
\hline & Total & 152 & $100 \%$ \\
\hline \multirow[t]{6}{*}{4.} & Work & & \\
\hline & PNS & 3 & $2 \%$ \\
\hline & businessman & 14 & $9.2 \%$ \\
\hline & $\begin{array}{l}\text { Private } \\
\text { employees }\end{array}$ & 9 & $5.9 \%$ \\
\hline & $\begin{array}{l}\text { Student / } \\
\text { Student }\end{array}$ & 126 & $82.9 \%$ \\
\hline & Total & 152 & $100 \%$ \\
\hline \multirow[t]{6}{*}{5.} & Income / allowance per month & & \\
\hline & $<\mathrm{Rp} 1000.000,00$ & 79 & $52 \%$ \\
\hline & $\begin{array}{l}\text { Rp 1000.000,00 } \\
\text { - Rp 2,999,999.00 }\end{array}$ & 54 & $35.5 \%$ \\
\hline & $\begin{array}{l}\operatorname{Rp} 3000.000,00 \\
-\operatorname{Rp} 4,999,999.00\end{array}$ & 14 & $9.2 \%$ \\
\hline & $>$ USD 5000.000,00 & 5 & $3.3 \%$ \\
\hline & Total & 152 & $100 \%$ \\
\hline
\end{tabular}

Source: Processed, 2018

\section{Validity Test}

Research variables used in the study is the result of a set of indicators obtained from the distribution of questionnaires so that the resulting data are necessary to test the truth or validity. In this study testing the validity of the instrument used was Confirmatory Factor Analysis (CFA). In the CFA we must also look at the output of the rotated component matrix must extract completely, then the process of testing the validity by factor analysis should be repeated by removing the item that question is two- sided. In addition, to examine the interrelated variables is shown by the value of determination (R) which is close to 0, the value KMO (Keizer- Meyer-Olkin) must be greater than 0.5, Bartlett test and test MSA (Measure of Sampling Adequency). Based on Table 1, shows that the value of the column and KMO MSA in accordance with predetermined criteria which must be greater than 0.5 . Thus, it appears that all the statements contained in the study variables as valid as it has meet criteria and KMO MSA standard value of more than 0.5 .

\section{Reliability Test}

The use of the items the question as an indicator of research variable data requires an examination of consistency through the reliability test, so that the data used is actually trustworthy or meet the reliability aspects for further analysis. Reliability test in this study conducted by calculating Cronbach alpha of each instrument in a variable. Size is deemed reliable reliability based on Cronbach alpha coefficient of more than 0.60 (Malhotra, 2009). 
Table 2. Results of Validity Test

\begin{tabular}{|l|l|c|} 
No. & \multicolumn{1}{|c|}{ Item Price Premium } & Payload Factor \\
\hline 1. & $\begin{array}{l}\text { I am willing to pay a higher price for the product } \\
\text { Brand J.CO than other brands }\end{array}$ & 0.951 \\
\hline 2. & $\begin{array}{l}\text { I am willing to pay more for brands J.CO in this } \\
\text { category }\end{array}$ & 0.968 \\
\hline 3. & $\begin{array}{l}\text { I am willing to pay less than a percentage to get the } \\
\text { brand of the other brands }\end{array}$ & 0.933 \\
\hline Eigenvalues & 2,713 \\
\hline Variance can be explained (\%) & 90.416 \\
\hline Kaiser-Meyer-Olkin Measure of Sampling Adequacy & 0,745 \\
\hline Bartlett's Test of Sphericity & 0,000 \\
\hline
\end{tabular}

Source: SPSS output 20 (processed), 2018

\begin{tabular}{|l|l|l|c|c|c|}
\multirow{2}{*}{ No } & \multirow{2}{*}{ Independent Item } & \multicolumn{4}{|c|}{ Payload Factor } \\
\cline { 4 - 6 } & & $\mathbf{1}$ & $\mathbf{2}$ & $\mathbf{3}$ & $\mathbf{4}$ \\
\hline $\mathbf{1}$ & KM 1 & & 0.684 & & \\
\hline $\mathbf{2}$ & KM 2 & & 0.797 & & \\
\hline $\mathbf{3}$ & KM3 & & 0.736 & & \\
\hline $\mathbf{4}$ & KM4 & & 0.777 & & \\
\hline $\mathbf{5}$ & KM5 & & 0.593 & & \\
\hline $\mathbf{6}$ & PK1 & & & & 0.821 \\
\hline $\mathbf{7}$ & PK2 & & & & 0.801 \\
\hline $\mathbf{8}$ & PK3 & 0.793 & & & \\
\hline $\mathbf{9}$ & UNIK1 & 0.809 & & & \\
\hline $\mathbf{1 0}$ & UNIK2 & 0,848 & & & \\
\hline $\mathbf{1 1}$ & UNIK3 & 0.843 & & & \\
\hline $\mathbf{1 2}$ & UNIK4 & & & 0,806 & \\
\hline $\mathbf{1 3}$ & CS1 & & & 0.886 & \\
\hline $\mathbf{1 4}$ & CS2 & & & 0.889 & \\
\hline $\mathbf{1 5}$ & CS3 & & & \\
\hline
\end{tabular}

Source: SPSS output 20 (processed), 2018

Table 3. Results Reliability Test

\begin{tabular}{|l|l|c|l|l|}
\hline No & Variables & Variable Item & Alpha Value & Reliability \\
\hline 1. & Brand awareness & 5 & 0.891 & reliable \\
\hline 2. & Perception of Quality & 3 & 0.919 & reliable \\
\hline 3. & Uniqueness & 4 & 0.933 & reliable \\
\hline 4. & Social imagery & 3 & 0.944 & reliable \\
\hline 5. & Price Premium & 3 & 0.952 & reliable \\
\hline
\end{tabular}

\section{Hypothesis Testing}

Hypothesis testing is done by using multiple regression analysis to determine the effect of variables, which include (1) Brand Awareness affect J.CO Price Premium in Banda Aceh as hypotheses 1, (2) perceived quality affects Price Premium on J.CO Banda Aceh as hypothesized 2, (3) uniqueness affect J.CO Price Premium in Banda Aceh as hypothesis 3 (4) Social imagery affects Price Premium on J.CO Banda Aceh as a hypothesis 4.

Based on the results of the regression analysis in Table 4.13 shows that brand awareness significantly influence the Price Premium with a significant level of 0.004 , with a level of significance is less than the significance level of $5 \%$, brand awareness significantly influence the price premium and the value of regression coefficient $(\beta)$ of -0.157 . Perceived Quality significant effect on Price Premium with a significant level of 0.001 , with a level of significance is less than the significance level of $5 \%$, then the perception of quality significantly influence the price premium and the value of regression coefficient $(\beta)$ of 0.179 , uniqueness significant effect on Price Premium significant level of 0.018 , with the level of significance is less than thesignificance level of 5\%, then the uniqueness significant effect on the price premium and the value of regression coefficient $(\beta)$ of 0.118 , Citra Socially significant effect on Price Premium with a significant level of 0.000, with a level of significance is 
less than the level the uniqueness of significance $5 \%$, significantly influence the price premium and the value of regression coefficient $(\beta)$ of 0.761 . It can be concluded that the hypothesis 1 , hypothesis 2 , hypothesis 3 , the hypothesis 4 is supported. with a significance level of less than $5 \%$ significance level then the uniqueness significant effect on the price premium and the value of regression coefficient $(\beta)$ of 0.761 . It can be concluded that the hypothesis 1 , hypothesis 2 , hypothesis 3 , the hypothesis 4 is supported. with a significance level of less than 5\% significance level then the uniqueness significant effect on the price premium and the value of regression coefficient $(\beta)$ of 0.761 . It can be concluded that the hypothesis 1 , hypothesis 2 , hypothesis 3 , the hypothesis 4 is supported. The results of this research hypothesis testing are summarized in the following table:

Table 4. Result Analysis of Effect of Brand Awareness, Perceived Quality, Uniqueness and Social Imagery Against Price Premium on J.CO Banda Aceh

\begin{tabular}{|c|c|c|c|}
\hline & $\begin{array}{c}\text { standardized } \\
\text { Coefficients } \\
\text { beta }\end{array}$ & & \\
Model & & $\mathrm{T}$ & Sig. \\
1 (Constant) & -.157 & 1,006 & .316 \\
& .179 & 3,269 & .004 \\
brand & .118 & 2,390 & .001 \\
awareness & .761 & 14181 & .000 \\
perceived & & & \\
quality & & & \\
Uniqueness & & & \\
Social & & & \\
imagery & & & \\
\hline
\end{tabular}

Table 5. Summary of Research Hypothesis Testing Results

\begin{tabular}{|l|l|c|}
\hline & \multicolumn{1}{|c|}{ Hypothesis } & Information \\
\hline H1 & Brand Awareness effect on Price Premium & Be accepted \\
\hline H2 & Quality perceptions affect the Price Premium & Be accepted \\
\hline H3 & The uniqueness of the effect on Price Premium & Be accepted \\
\hline H4 & Social imagery effect on Price Premium & Be accepted \\
\hline
\end{tabular}

\section{Conclusion}

Based on the research that has been described in the previous chapter, it can take the following conclusions and recommendations:

1. Brand awareness significantly influence the price premium. Brand awareness has a corresponding significant level that is equal to 0,004 and the value of regression coefficient of $0,-157$, which means the higher the price of Premium brand awareness will decrease during the J.CO.

2. Perception Quality significant effect on the price premium. Perception of quality has sgifikan appropriate level that is equal to 0,001 with regression coefficient of 0.179 , which means the higher the quality, the increasing Price Premium on J.CO.

3. Uniqueness significant effect on the price premium. Uniqueness has a significant level that is equal to 0,018 corresponding to the value of regression coefficient of 0.118 which means higher uniqueness, then increasing Price Premium on J.CO and the uniqueness of J.CO.

4. Social Imagery significant effect on the price premium. Social image has sgifikan appropriate level that is equal to 0,000 with regression coefficient of 0.761 , which means the higher the social image, then also increase the price premium on J.CO.

\section{Suggestion}

Based on the analysis that has been done in this study, the researchers put forward some suggestions as follows:

1. Based on the results of the descriptive imagery penenlitian Social, item inquiry "to buy products from J.CO made me accepted in the social environment" has the lowest mean value amounting to 3.49. And the results of this study Social Imagery variables affect the price premium on J.CO in Banda Aceh. So consumers who consume products from J.CO Surely received in the social environment.

2. Based on the results of the descriptive penenlitian perceived quality, item question "J.CO products have high quality standards" has the lowest mean value amounting to 4.13. And the results of this research affect the perception of quality Premium price on J.CO in Banda Aceh. So J.CO companies must improve product quality. 
3. Based on the results of the descriptive uniqueness, the item question "J.CO products are very different from other products" has the lowest mean value is 3.88. The uniqueness of this study and the results affect the Price Premium on J.CO in Banda Aceh. So consumers who have opinions that J.CO no difference from other products the company should pay attention more to be different from competitors' products.

4. Based on the results of descriptive brand awareness, the item question "I have a positive opinion about the brand J.CO" has the lowest mean value amounting to 3.94. And the results of this research have brand awareness affects Price Premium on J.CO in Banda Aceh. J.CO conduct sales promotion or publiksi in order to create a more positive opinion of the brand J.CO.

\section{References}

Ali. (2010). Influence of Brand Image on konsmen willingness to pay apremium price Starbucks Product, Program Management Studies, Faculty of Economics, University of Atma Jaya Yogyakarta

Anselmsson, J., Johansson, U. And Persson, N. (2007). Understanding the premium price for grocery products: a conceptual models of customer- based brand equity", Journal of Product \& Brand Management, Vol. 16 No. 6, pp. 401-414.

Anselmsson, J. Et al. (2014). brand image and customers' willingness to pay a price premium for Food Brand. Journal of product \& Brand Management, 23 (2), pp. 90-102.

Atwal \& Wiliam. (2009). Predicting early career research productivity. The case of management faculty. Journal of Organizational Behavior.

Buchory. (2010). Influence of Brand Image on kosmen willingness to pay a premium price prosuk Starbucks, Program Management Studies, Faculty of Economics, University of Atma Jaya Yogyakarta.

Elliot \& Wattanusawan. (1998). Predicting early career research productivity. The case of management faculty. Journal of Organizational Behavior.

https://www.maxmanroe.com/melihat- sejarah-bisnis-j-co-donut- coffee.html

http://agung- ananda.blogspot.co.id/2011/10/j co-donuts-coffee.html

Harrison. (2001). The Measurement of Word-of-Mouth. Communication and an Investigation of Service Quality and Customer. Commitment as Potential antecedents. Journal of Service Research.

He et al. (2012). Consumer evaluation of technology-based vertical brand extension. European Journal of Marketing, 44 (9), 1366-1383.

Keller. (1993). Understanding the premium price for grocery products: a conceptual models of customerbased brand equity", Journal of Product \& Brand Management, Vol. 16 No. 6, pp. 401-414.

Keller. (2009). The Effect of Brand Equity On Price Premium of Apple Iphone, EMBA Journal, Vol. 14 December 2013, p. 542-549.

Malhotra, NK. ( 2009). Marketing Research, Fourth Edition, Volume 1, PT Index, Jakarta

Matthew JW. (2013). The Effect of Brand Equity On Price Premium of Apple Iphone, EMBA Journal, Vol. 14 December 2013, p. 542-549.

Netemeyer, RG, Krishan, B., Pullig, C., Wang, G., Yagci, M., Dean, D., Ricks, J. And Wirth, F. (2004). Developing and validating measures of Facets of customer- based brand equity, Journal of Business Research, Vol. 57 No. 2, pp. 209-224

Tsai Shu-pei. (2005). Impact of personal orientation on luxury- brand purchase value: An international investigation, Vol. 47 Iss 4, pp. 429-454 